\title{
38. CENOZOIC OSTRACODES OF THE VORING PLATEAU (ODP LEG 104, SITES 642, 643, AND 644) ${ }^{1}$
}

\author{
Heinz Malz ${ }^{2}$
}

\begin{abstract}
Ostracodes are less common than might be normally expected at Sites 642,643 , and 644 , perhaps pointing to the fact that the marine habitat below the overlying Pleistocene ice covers was a severe environment. This explanation, however, would not apply to the Pliocene and Miocene deposits from which ostracodes are just as poorly represented. In the latter case the Iceland-Faeroe Ridge might still have acted as a submerged barrier that did not allow an open ocean circulation of bottom waters. Thus the barrier presumably prevented an exchange of cold subarctic bottom water with that of the open Atlantic and therefore benthic deep-sea migration from the south was impeded. Some Quaternary species are, for the first time, recorded to extend to the Pliocene and/or Miocene.
\end{abstract}

\section{INTRODUCTION}

The first DSDP record dealing with ostracode faunas from nearly the same high latitude as the present study refers to the occurrence of deep-sea species from the Paleogene of Leg 12 (Benson, 1972). Further data on Paleogene to Neogene ostracodes were obtained from various sites of Leg 48 (Ducasse and Peypouquet, 1979). Both these legs are located on or near the Rockall Plateau. From Leg 81, the sites of which were drilled in the same area of the Rockall Plateau, no ostracodes were reported. Likewise, no ostracodes were encountered at DSDP sites 336 to 352 of Leg 38, which preceded the present research in almost the same area of the Norwegian-Greenland Sea. Therefore, the Leg 104 ostracodes yield the first distributional data on occurrences north of the Arctic Circle (Fig. 1).

Sixty samples containing ostracodes were examined from five holes $(642 \mathrm{~A}, 642 \mathrm{~B}, 642 \mathrm{C}, 643 \mathrm{~A}$, and $644 \mathrm{~A})$ in which sediments range in age from Miocene (642B, 643A), Pliocene (642C), and Pleistocene $(642 \mathrm{~A}, 644 \mathrm{~A})$ to Recent. The Miocene ostracodes were poorest in specimens (13) and only represent five species. Fifteen specimens belonging to four (or perhaps 5) species were determined from the Pliocene leaving 91 specimens of 22 species to the Pleistocene.

\section{MATERIAL AND METHODS}

The ostracodes were picked from the same samples from which the foraminifers had been obtained (Jansen and Spiegler, this volume). A total of 1157 samples were checked, but only 60 samples (about 5\%) contained ostracodes. This low percentage is exaggeratedly high, considering the small number of specimens per sample. More than 30 samples contained a single specimen, 15 contained two specimens each, and the maximum of 7 specimens per sample is documented in just 3 samples.

Therefore, the total of 119 specimens obtained from 60 samples leads to the meager average of less than 2 specimens per sample and, as a result the study area appears as a nonostracodal habitat. This explanation is supported by the fact that most of the specimens are juveniles, which appear to be mislead and lost scouts in a severe environment.

The identification of juvenile specimens is impeded for two reasons: (a) the descriptions and illustrations of species refer almost exclusively to adult specimens and neglect the juveniles, and (b) characteristic fea-

\footnotetext{
${ }^{1}$ Eldholm, O., Thiede, J., Taylor, E., et al., 1989. Proc ODP, Sci. Results, 104: College Station, TX (Ocean Drilling Program).

${ }^{2}$ Forschungs-Institut Senckenberg, Senckenberg-Anlage 25, D-6000 Frankfurt am Main 1, Federal Republic of Germany.
}

tures of the adult specimens are not well developed in juveniles, even fading in younger moult stages. Therefore the specific determination of the juveniles had to be achieved by comparative studies on material (which is at our disposal from the collections of fossil and Holocene ostracodes at the Senckenberg Museum) containing ontogenetic suites of the presumed species. Thus, some of the recorded juveniles could be identified, but some remain uncertain.

\section{OSTRACODES FROM THE VARIOUS SITES}

The ostracodes are generally well preserved but, as mentioned, occur in very small numbers only, which by itself causes low species diversity. Most of the identified species are still extant and thus not very conclusive for stratigraphic purposes. In part, they are bound to high latitudes today (Pterygocythereis mucronata, Finmarchinella finmarchica, Rabilimis mirabilis) or occur eurythermally in arctic to temperate faunas (Acanthocythereis dunelmensis, Argilloecia conoidea, Cytheropteron alatum), which, to some extent, helps to elucidate ecological conditions. Among the extinct Pleistocene species Roundstonia globulifera is well known for its circumpolar distribution and Cytheropteron arcuatum represents "almost certainly a true, Arctic species" (Whatley and Masson, 1979), whereas Cytheropteron testudo and Henryhowella asperrima tolerate rather eurythermal conditions.

Only benthic ostracodes are found in Sites 642 to 644 cores, and they indicate exclusively marine conditions. Some of the species live over broad depth ranges, neritic to bathyal or even abyssal, and therefore paleobathymetric conclusions are impeded.

However, combining the various ecological and stratigraphical aspects of the different species with other factors such as distribution data and composition of faunas in nearby onshore drillings in southwest Norway (Lord, 1980), even the sporadic occurrences of these ostracodes can be linked tentatively to some of the known events.

\section{Site 642 (Tables 1-3)}

Holes A to E were drilled at Site $642\left(67^{\circ} 13.5^{\prime} \mathrm{N}, 02^{\circ} 55.7^{\prime} \mathrm{E}\right.$; water depth $1286 \mathrm{~m}$ ). Hole $642 \mathrm{~A}$ was terminated in Pleistocene deposits at 10.8 (mbsf). Five samples of Core $642 \mathrm{~A}-1 \mathrm{H}$ contained 14 specimens, mainly juveniles of Krithe sp. The occurrence of four more species is listed in Table 1. Holes 642B and $642 \mathrm{C}$ penetrated Pleistocene and Pliocene deposits down to the Miocene and were terminated in sediments void of calcareous fossils at $221.1 \mathrm{mbsf}$ and $199.6 \mathrm{mbsf}$, respectively. Thirteen samples from Hole 642B contained 19 specimens; i.e., three speci- 


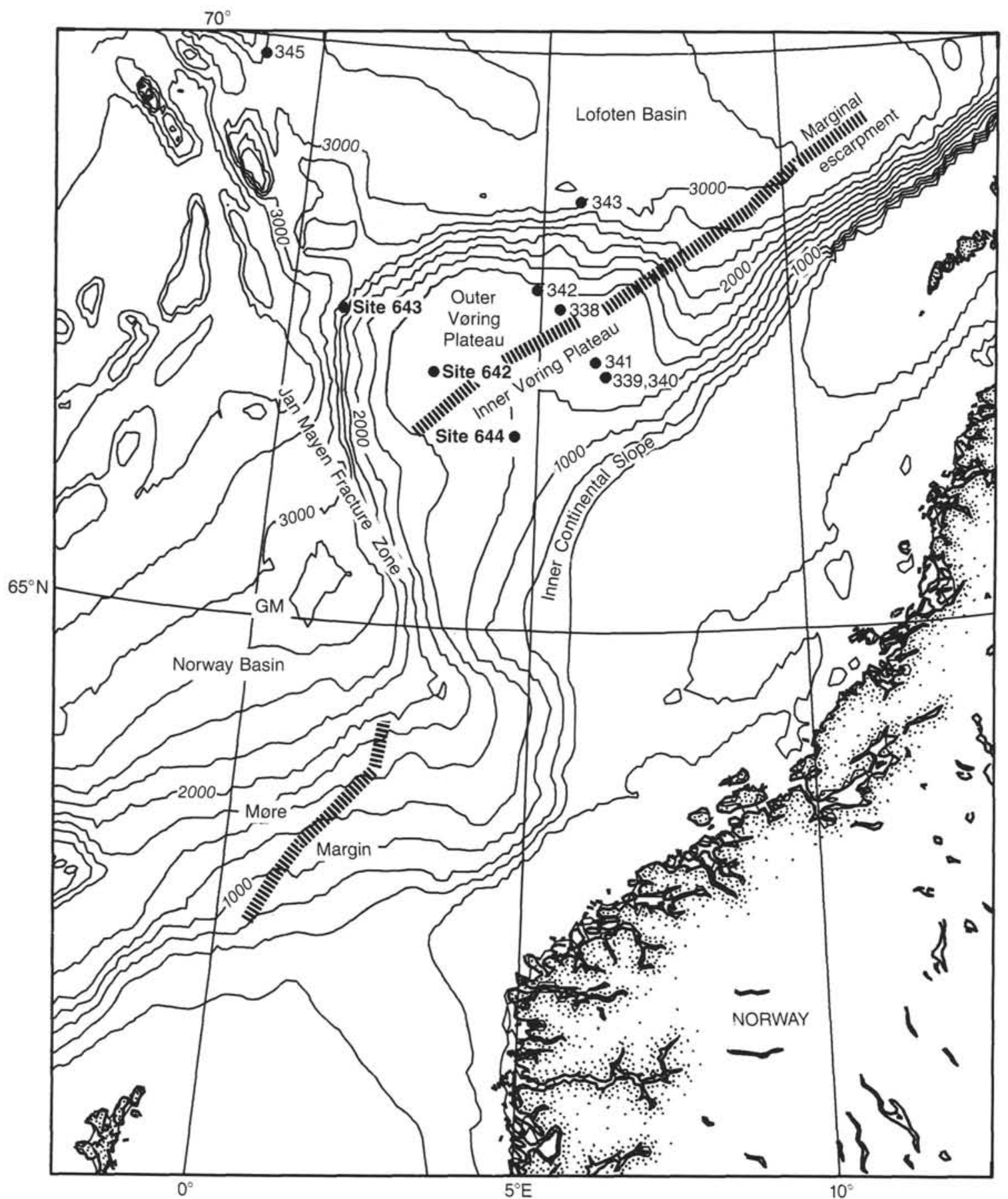

Figure 1. Location map of Sites 642,643 , and 644 (Leg 104). Bathymetry of the Norwegian Continental margin, $60^{\circ}-70^{\circ} \mathrm{N}$ (contour interval, $250 \mathrm{~m})$.

mens assigned to the Pleistocene, seven to the Pliocene, leaving nine to the Miocene (for distribution and identification of species see Table 2). Even fewer ostracodes were obtained from Hole $642 \mathrm{C}$ in which six samples contained only ten ostracodes (Table 3). Holes 642D and 642E were barren of ostracodes.

\section{Site 643 (Table 4)}

Hole A was drilled at Site $643\left(67^{\circ} 42.9^{\prime} \mathrm{N}, 01^{\circ} 02.0^{\prime} \mathrm{E}\right.$; water depth $2753 \mathrm{~m}$ ) penetrating the Pleistocene to Eocene and terminating at 565.2 mbsf. Ostracodes occur very rarely in Hole 643A (five samples contained six specimens).

\section{Site 644 (Table 5)}

Hole $644 \mathrm{~A}\left(66^{\circ} 40.7^{\prime} \mathrm{N}, 04^{\circ} 34.6^{\prime} \mathrm{E}\right.$; water-depth $\left.1227 \mathrm{~m}\right)$ penetrated the Pleistocene and was terminated in Pliocene deposits at $252.8 \mathrm{mbsf}$. The Pleistocene sequence reaches about $165 \mathrm{~m}$ in thickness, but only the uppermost $126 \mathrm{~m}$ contained ostracodes. Seventy specimens were obtained from 31 samples (Table 5). The poor fauna is dominated by juvenile Krithe sp. and various species of Cytheropteron. The diversity of the Cytheropterons points to more temperate conditions and thus they appear to be indicative of interglacial periods. This assumption may be emphasized by correlation with the occurrence of plank- 
Table 1. Pleistocene Ostracodes from Hole 642A.

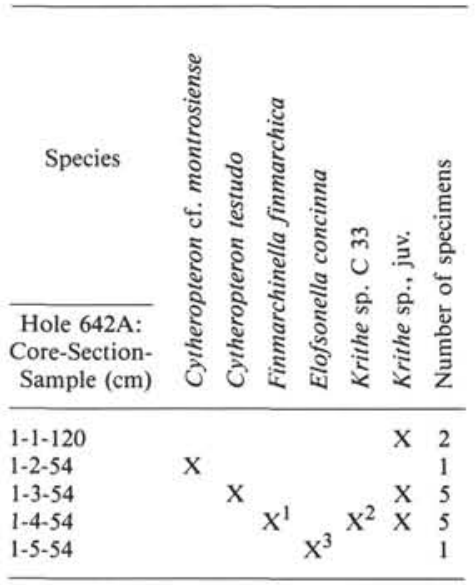

For illustration: ${ }^{1}$ Plate 1 , item $6 .{ }^{2}$ Plate 2 , items 2.3. ${ }^{3}$ Plate 2 , item 1 .

Table 2. Pleistocene to Miocene Ostracodes from Hole 642B.

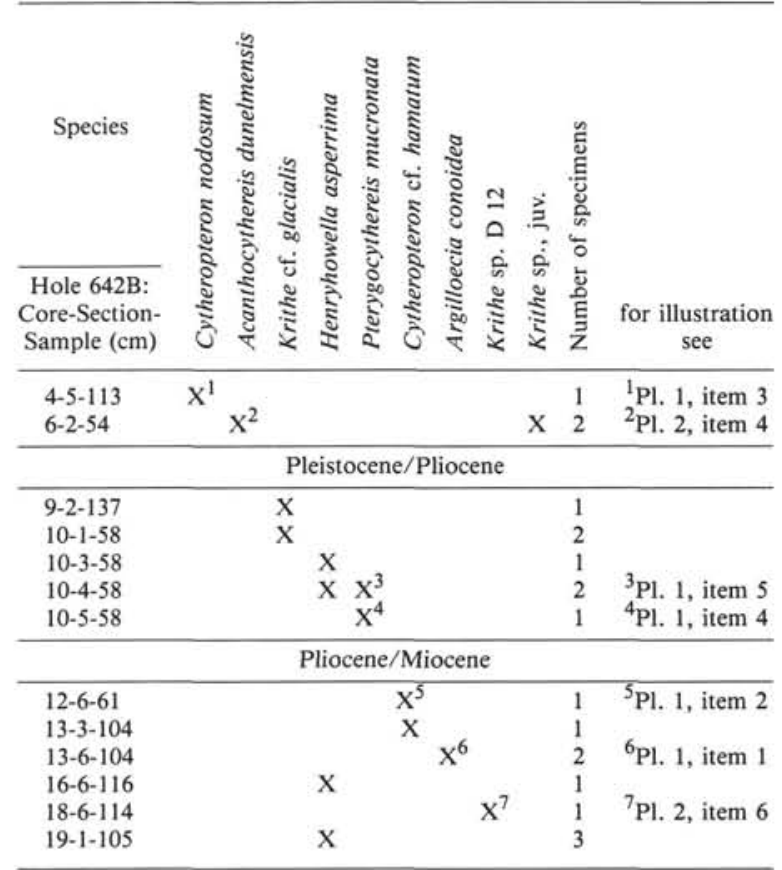

tonic foraminifers. Because their occurrence is confined to interglacial and interstadial periods (D. Spiegler, pers. commun.), the diverse Cytheropterons also probably highlight temperate conditions. On the other hand Krithe could have survived in cold water conditions living submerged in haitats covered by glacial ice shields.

\section{STRATIGRAPHICAL AND PALEOBIOGEOGRAPHICAL IMPLICATIONS}

For some of the extant species the stratigraphical range was found to extend to the Pliocene, or even to the Miocene, respectively, as can be demonstrated by the occurrence of Pterygocythereis mucronata in Core 104-642B-10, and Argilloecia conoidea in Core 104-642B-13 (Table 2). In the case of Cytherop-
Table 3. Pliocene/Pleistocene

Ostracodes from Hole $642 \mathrm{C}$.

\begin{tabular}{|c|c|c|c|}
\hline Species & 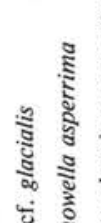 & 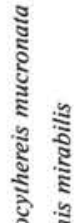 & 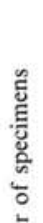 \\
\hline $\begin{array}{l}\text { Hole } 642 \mathrm{C}: \\
\text { Core-Section- } \\
\text { Sample }(\mathrm{cm})\end{array}$ & 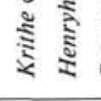 & 气ूँ & 兽 \\
\hline $4-4-32$ & $\mathrm{x}$ & & 1 \\
\hline \multicolumn{4}{|c|}{ Pleistocene/Pliocene } \\
\hline $9-1-116$ & $x^{1}$ & & 2 \\
\hline $10-4-113$ & $\mathrm{X}$ & & 1 \\
\hline $10-6-113$ & $\mathrm{x}$ & & \\
\hline $11-1-114$ & & $x \quad x$ & 3 \\
\hline $11-6-114$ & $\mathrm{x}$ & & 2 \\
\hline
\end{tabular}

For illustration: ${ }^{1} \mathrm{Pl} .1$, item 7.

Table 4. Pleistocene to Miocene Ostracodes from Hole 643A.

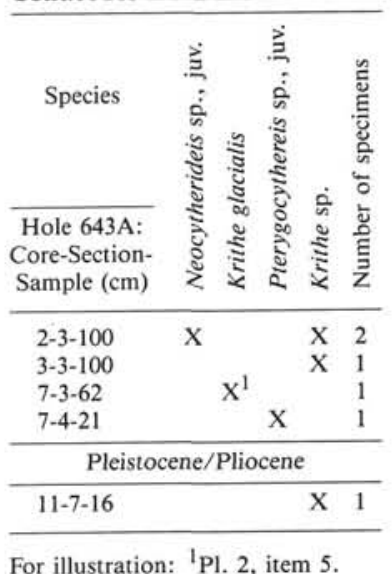

teron cf. hamatum, the extended range to the Miocene needs further support from more localities. Rabilimis mirabilis, which generally appears as a boreal to arctic species from Pleistocene to Holocene, is first recorded from Pliocene deposits in Core 104-642C-11 (Table 3).

An optimum depth for all ostracodes identified from the samples falls normally within the littoral zone $(\leq 200 \mathrm{~m})$. As mainly single specimens occur, presumably none of the species was found in its optimum habitat. Therefore, single specimens indicate extreme conditions in much deeper depositional environments than those where they normally are found. There is no sign of downslope transportation, as the specimens are generally well preserved. The ice cover during the Pleistocene apparently did not encourage ostracodes to develop large populations or diverse assemblages of species. But as the Miocene and Pliocene faunas are just as poorly represented, paleogeographical reasons could be responsible for these meager faunas. Although the connection of the Norwegian-Greenland Sea with the Atlantic had already been accomplished at that time, the IcelandFaeroe Ridge might have acted as a submerged barrier to keep the cold subarctic environment separate from oceanic influence. As a consequence, no deep-sea genera, such as Agrenocythere, Bradleya, or Poseidonamicus, were encountered in the ostracode faunas. 
Table 5. Ostracode log for Hole 644A (Pleistocene).

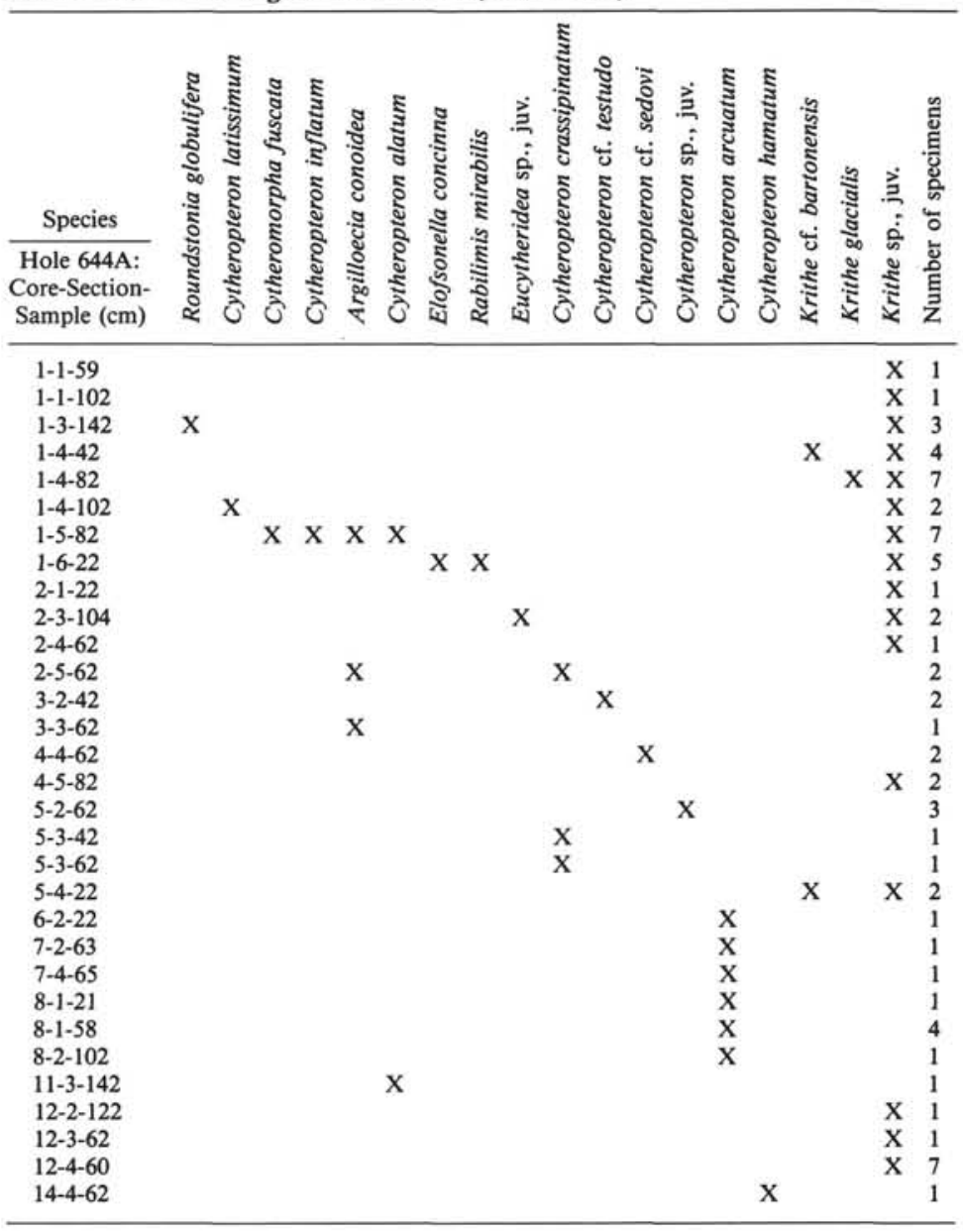

\section{TAXONOMIC ANNOTATIONS}

The following notes discuss distributional data of Leg 104 species with those quoted from other areas.

Acanthocythereis dunelmensis (Norman, 1865) (Plate 2, item 4). This species is known as living from the Arctic to boreal regions in the North Atlantic, North Sea (type locality), and southwestern Baltic Sea in shallow-water habitats. It is also recorded from the Hoxnian Interglacial of Great Britain (Robinson, 1978), the Holsteinian of Denmark (Bassiouni, 1965), the Pleistocene/Holocene boundary of southwest Sweden (Lord, 1982), and from the Weichselian of southwest Norway (Lord, 1980). Size variants have been split into species and subspecies by Bassiouni (1965), but his work needs to be reviewed with more material.

Argilloecia conoidea Sars, 1923 (Plate 1, item 1). The living species was first recorded from the North Sea (type area). Subsequently it has been recorded from the northern continental margin of the Bay of Biscay ranging to the early Pliocene (Ducasse and Peypouquet, 1979). Its Miocene occurrence in Hole 642B sediments refers to a somewhat smaller specimen showing the same outline as the Holocene forms.

Cytheropteron alatum Sars, 1866 was first described from Oslo Fjord, Norway, where it occurs in moderately deep water. In reviewing the species, Whatley and Masson (1979) came to the conclusion that it might be restricted to the boreal region of the northeastern Atlantic. From the literature it appears that the species also occurs living in the Mediterranean (Bonaduce et al., 1976), where it ranges down to the Pliocene (Sissingh, 1972).

Cytheropteron cf. hamatum Sars, 1869 (Plate 1, item 2). According to Whatley and Masson (1979) the species had been found in Holocene sediments only. Therefore its early occurrence in the Miocene of Hole 642B needs further support with data from more localities.
Cytheropteron cf. montrosiense Brady, Crosskey, and Robertson, 1874. This species is also recorded from the Hoxnian Interglacial of Great Britain (Robinson, 1978) and from the Pleistocene/Holocene boundary in southwest Sweden (Lord, 1982). It appears to be restricted to the Pleistocene (Whatley and Masson, 1979).

Cytheropteron nodosum Brady, 1868 (Plate 1, item 3) is widely distributed in the eastern Atlantic at high latitudes between $45^{\circ} \mathrm{N}$ and $70^{\circ} \mathrm{N}$ and is a common species in Pleistocene sediments of northwestern Europe (Whatley and Masson, 1979).

Cytheropteron testudo Sars, 1870 is mainly recorded from Pleistocene to Holocene sediments of the North Atlantic, North Sea, and Skagerrak (Peypouquet, 1977). The earliest record of the species is from the middle Pliocene of Italy (Bonaduce and Sprovieri, 1985).

Elofsonella concinna Jones, 1857 (Plate 2, item 1) is a common boreal to arctic species. It is also recorded from the Holsteinian Interglacial of Denmark (Bassiouni, 1965), from the Hoxnian Interglacial of Great Britain (Robinson, 1978), from the Weichselian of southwest Norway (Lord, 1980), and from the Pleistocene/Holocene boundary in southwest Sweden (Lord, 1982).

Finmarchinella finmarchica Sars, 1863 (Plate 1, item 6) is a common boreal to arctic species. Its fossil record extends to the Pleistocene of Great Britain, southwest Norway, and southwest Sweden (Lord, 1982). Recently it was encountered in Pleistocene strata of DSDP Holes 612 and 613, off New Jersey (Cronin and Compton-Gooding, 1987).

Henryhowella asperrima Reuss, 1850, s.1. (Plate 1, item 7). From the literature it appears that the species is geographically, stratigraphically, and bathymetrically widely distributed. It is recorded from various DSDP holes in the North and South Atlantic as well as from the northwest German Tertiary Basin, the Vienna Basin (its type area) and from the Mediterranean. Notwithstanding its Holocene occurrence, the fossil record for the species ranges from the Quaternary to 
the middle Eocene (Ducasse and Peypouquet, 1979) including occurrences from abyssal paleodepths ( $>4000 \mathrm{~m}$ ) to littoral habitats. Breman (1976) found an optimum depth for this species of between 120 and $200 \mathrm{mbsf}$ in the Adriatic Sea, whereas Cronin (1983) reported the maximum to occur below 750 mbsf in highly oxygenated water below $8^{\circ} \mathrm{C}$ on the Florida-Hatteras slope. Certainly the concept of the species needs revision as it covers different size ranges and ornament patterns at the various localities and stratigraphic levels. Repeatedly, the great variability of the species has been subject to detailed studies regarding its size and ornamentation. Uffenorde (1981, p. 148) pointed out that the $\mathrm{L} / \mathrm{H}$ ratio decreases gradually from the upper Oligocene to upper Miocene in specimens from the northwest German Tertiary Basin. Because single specimens from the DSDP holes cannot be judged as representative, the general use of the $\mathrm{L} / \mathrm{H}$ ratio as a stratigraphical indicator remains to be confirmed by more specimens. Therefore, the rare specimens found in the Holes 642B and $642 \mathrm{C}$ are not conclusive for stratigraphical purposes.

Krithids generally occur in deep-sea sediments in a great number of distinctly diverse forms pointing to a wide spectrum of different species. Among these Krithe glacialis Brady, Crosskey, and Robertson, 1874 (Plate 2, item 5) appears to be restricted to Pleistocene and Holocene cold water habitats of the northern Atlantic. Most of the other species are still unnamed or have been published under open nomenclature. Thus, a numerical classification helps to delineate the various forms against each other by means of size, outline, $\mathrm{L} / \mathrm{H}$ ratio, the contours of the marginal zone and its vestibule, as well as the number and distribution of the marginal pore canals (Peypouquet, 1977). Translation of all these features to a numerical classification comes close to creating a detailed species concept, which is of considerable help for further biogeographical and stratigraphical conclusions.

Pterygocythereis mucronata Sars, 1866 (Plate 1, items 4,5) was first recorded off the Lofoten Island and, among other modern ostracodes, it characterizes the Holocene Norwegian Sea fauna (Lord, 1980). Its occurrence in strata of Holes $642 \mathrm{~B}$ and $642 \mathrm{C}$ represents the earliest record of the species in Pliocene deposits.

Rabilimis mirabilis Brady, 1868 occurs as a cool-water form at high latitudes in the eastern Atlantic ocean from Greenland to the Siberian shelf. The earliest record of the species is from the Hoxnian Interglacial of Great Britain (Robinson, 1978) which corresponds to the Holsteinian Interglacial of northern Germany. Therefore the record of the species in Hole $642 \mathrm{C}$ gives the first evidence for its Pliocene occurrence.

\section{ACKNOWLEDGMENTS}

Thanks go to Dr. D. Spiegler (Geologisch-Paläontologisches Institut, Universität Kiel) for offering the Leg 104 material for study, and to D. Klein for producing the photographs and typing the manuscript. Joseph E. Hazel and Alan R. Lord kindly reviewed the manuscript. All the ostracodes listed in Tables 1 to 5 and Plates 1 and 2 are deposited in the Forschungs-Institut Senckenberg, Frankfurt am Main (SMF Xe 13930, continuing).

\section{REFERENCES}

Bassiouni, M.A.A., 1965. Über einige Ostracoden aus dem Interglazial von Esbjerg. Medd. Dan. Geol. Foren., 15:507-518.
Benson, R. H., 1972. Preliminary Report on the Ostracodes of Holes 117 and 117A. In: Laughton, A. S., Berggren, W. A. et al., Init. Repts. DSDP, 12: Washington (U.S. Govt. Printing Office), 427432.

Benson, R. H., and Peypouquet, J.-P., 1983. The upper and midbathyal Cenozoic ostracode faunas of the Rio Grande Rise found on Leg 72 Deep Sea Drilling Project. In Barker, P. F., Carlson, R. L., et al., Init. Repts. DSDP, 72: Washington (U.S. Govt. Printing Office), 805-818.

Breman, E., 1976. The Distribution of Ostracodes in the Bottom Sediments of the Adriatic Sea [Ph. D. Thesis]. University of Amsterdam, The Netherlands.

Bonaduce, G., Ciampo, G., and Masoli, M., 1976. Distribution of Ostracoda in the Adriatic Sea. Pubbl. Staz. Zool. Napoli, 40: Suppl. 1, $1-154$.

Bonaduce, G., and Sprovieri, R., 1985. The appearance of Cytheropteron testudo Sars (Crustacea: Ostracoda) is a Pliocene event. Evidences from a Sicilian sequence (Italy). Bol. Soc. Paleontol. Ital., 23:131-136.

Cronin, T. M., 1983. Bathyal ostracodes from the Florida-Hatteras slope, the Straits of Florida, and the Blake Plateau. Mar. Micropaleontol., 6:89-119.

Cronin, T. M., and Compton-Gooding, E. E., 1987. Cenozoic ostracoda from Deep Sea Drilling Project Leg 95 off New Jersey (sites 612 and 613). In Poag, C. W., Watts, A. B. et al., Init. Repts. DSDP, 95: Washington (U.S. Govt. Printing Office), 439-451.

Ducasse, O., and Peypouquet, J.-P., 1979. Cenozoic ostracodes: their importance for bathymetry, hydrology, and biogeography. In Montadert, L., and Roberts, D. G., Init. Repts. DSDP, 48: Washington (U.S. Govt. Printing Office), 343-369.

Lord, A., 1980. Weichselian (Late Quaternary) ostracodes from the Sandnes Clay, Norway. Geol. Mag., 117:227-242.

1982. Ostracodes. In Olausson, E. (Ed.), The Pleistocene/ Holocene boundary in South-Western Sweden. Sver. geol. Unders., Ser. C, 794, 137-147.

Neale, J. W., 1983. The Ostracoda and Uniformitarism. I. The later record: Recent, Pleistocene and Tertiary. Proc. Yorks. Geol. Soc., 44: 305-326.

Peypouquet, J.-P., 1977. Les ostracodes et la connaissance des paléomilieux profonds. Application au Cénozoique de L'Atlantique nordoriental [Ph. D. Thesis]. University of Talence, Bordeaux, France.

Robinson, E., 1978. The Pleistocene. In Bate, R. H., and Robinson, E., (Eds.), A Stratigraphical Index of British Ostracoda. Liverpool, U.K. (Seal House Press), 451-457.

Sissingh, W., 1972. Late Cenozoic Ostracoda of the South Aegean Island Arc. Utrecht Micropaleontol. Bull., 6:1-187.

Uffenorde, H., 1981. Ostracoden aus dem Oberoligozän und Miozän des unteren Elbe-Gebietes (Niedersachsen und Hamburg; NW-deutsches Tertiärbecken). Palaeontographica, Abt. A, 172:103-198.

Whatley, R. C., and Masson, D. G., 1979. The ostracod genus Cytheropteron from the Quaternary and Recent of Great Britain. Rev. Esp. Micropaleontol., 11:223-277.

Date of initial receipt: 20 October 1987

Date of acceptance: 12 April 1988

Ms 104B-198 


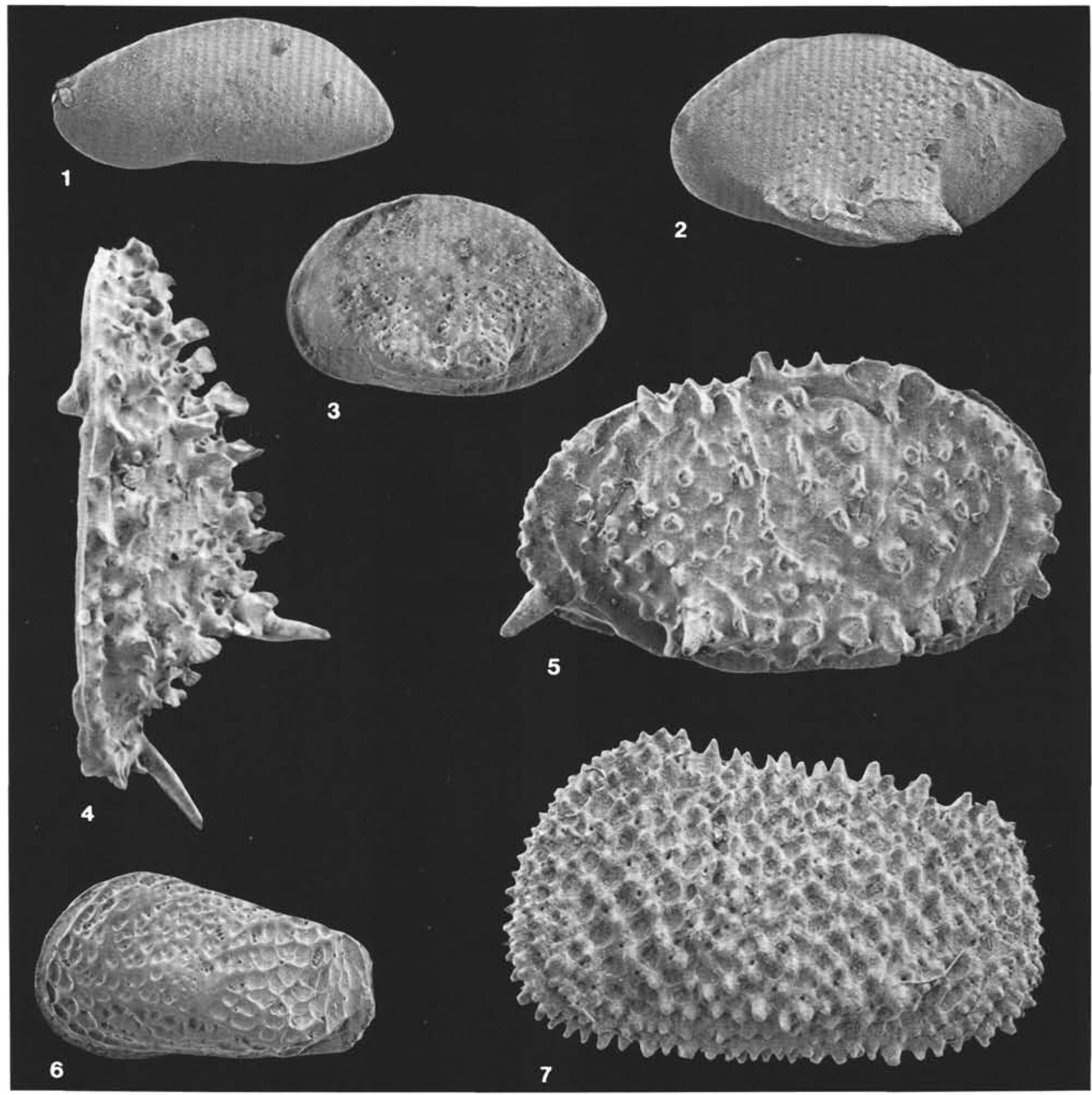

Plate 1. (Four-part designation beginning with 642A, 642B, or 642C refers to ODP Leg 104 Hole, Core, Section, and Sample number.) 1. Argilloecia conoidea Sars, 1923, $\times 100$, exterior left valve, Miocene, 104-642B-13-6, $104 \mathrm{~cm}, \mathrm{SMF}$ Xe 13930. 2. Cytheropteron cf. hamatum Sars, 1869, $\times 100$, exterior left valve, Miocene, 104-642B-12-6, $61 \mathrm{~cm}$, SMF Xe 13931. 3. Cytheropteron nodosum Brady, 1868, $\times 100$, exterior left valve, juvenile, Pleistocene, 104-642B-4-5, $113 \mathrm{~cm}$, SMF Xe 13932. 4, 5. Pterygocythereis mucronata (Sars, 1866), $\times 80$, (4) dorsal right valve, female, Pliocene, 104-642B-10-5, $58 \mathrm{~cm}$. SMF Xe 13933. (5) exterior right valve, female, Pliocene, 104-642B-10-4, $58 \mathrm{~cm}$, SMF Xe $13934 . \quad 6$. Finmarchinella finmarchica (Sars, 1863), exterior left valve, juvenile, Pleistocene, 104-642A-1-4, $54 \mathrm{~cm}$, SMF Xe 13935. 7. Henryhowella asperrima (Reuss, 1850), $\times 80$, exterior left valve, female, Pliocene, $104-642 \mathrm{C}-9-1,116 \mathrm{~cm}$, SMF Xe 13936 . The catalog numbers of the figured specimens refer to the ostracode collection of the Senckenberg Museum, Frankfurt am Main (SMF Xe). 

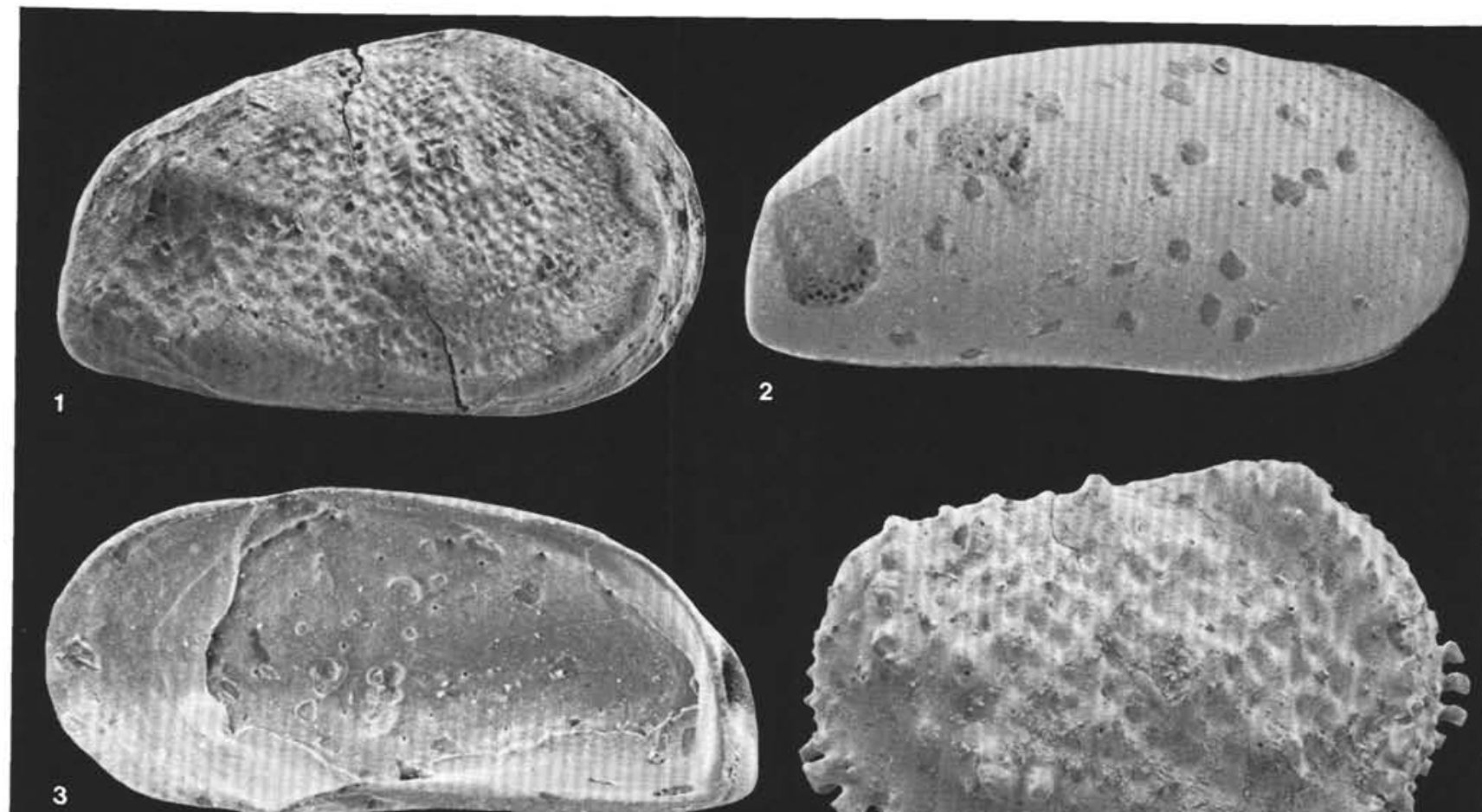

2
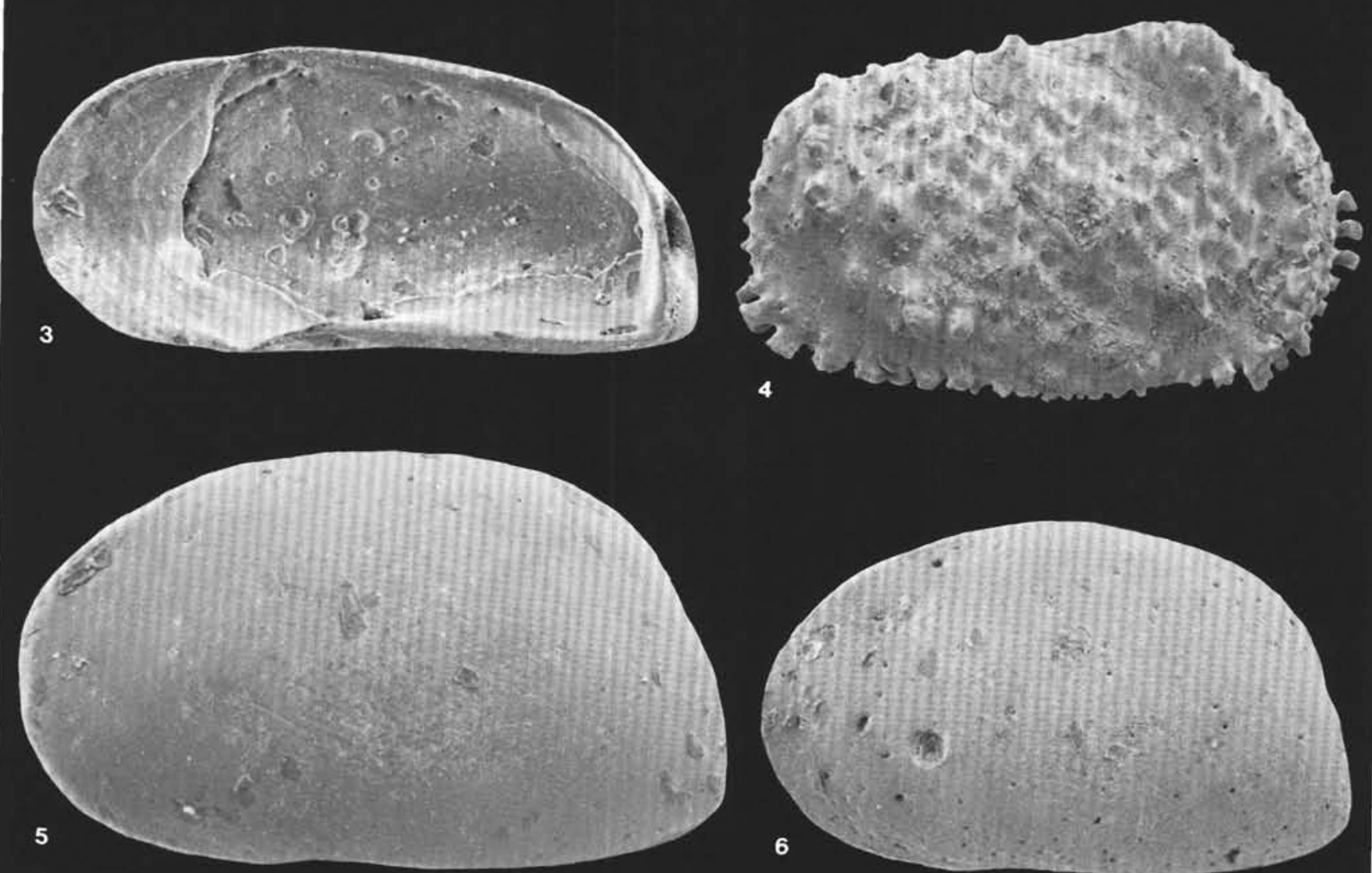

Plate 2. (Four-part designation beginning with 642A, 642B, or 643A refers to ODP Leg 104 Hole, Core, Section, and Sample number.) 1. Elofsonella concinna (Jones, 1857), $\times 100$, exterior right valve, juvenile, Pleistocene, 104-642A-1-5, $54 \mathrm{~cm}$, SMF Xe 13938. 2, 3. Krithe sp. C 33 Peypouquet, 1977, $\times 100$, (2) exterior right valve, (3) interior right valve, Pleistocene, 104-642A-1-4, $54 \mathrm{~cm}$, SMF Xe 13937. 4. Acanthocythereis dunelmensis (Norman, 1865), $\times 80$, exterior right valve, female, Pleistocene, 104-642B-6-2, $54 \mathrm{~cm}$, SMF Xe 13939. 5. Krithe glacialis Brady, Crosskey and Robertson, 1874, $\times 100$, exterior left valve, female, Pliocene, 104-643A-7-3, $62 \mathrm{~cm}$, SMF Xe 13940. 6. Krithe sp. D 12 Peypouquet, 1977 , $\times 100$, exterior left valve, female, Miocene, 104-642B-18-6, $114 \mathrm{~cm}$, SMF Xe 13941. The catalog numbers of the figured specimens refer to the ostracode collection of the Senckenberg Museum, Frankfurt am Main (SMF Xe). 